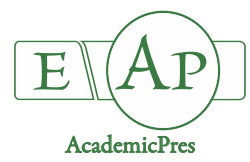

\title{
Phytochemical and Antioxidant Properties of Fresh Fruits and Some Traditional Products of Wild Grown Raspberry (Rubus idaeus L.)
}

\section{Bojana VELJKOVIĆ ${ }^{1 *}$, Violeta JAKOVLJEVIĆ ${ }^{1}$, Milan STANKOVIĆ Zora DAJIĆ-STEVANOVIĆ ${ }^{3}$}

\author{
${ }^{1}$ State University of Novi Pazar, Department of Biomedical Sciences, Vuka Karadžića bb, 36300 Novi Pazar, \\ Serbia; bojana.radulovic@yahoo.com (*corresponding author); jakovljevicvioleta@gmail.com \\ ${ }^{2}$ University of Kragujevac, Faculty of Sciences, Institute for Biology and Ecology, Radoja Domanovića 12, 34000 Kragujevac, \\ Serbia; mstankovic@kg.ac.rs \\ ${ }^{3}$ University of Belgrade, Department of Agrobotany, Nemanjina 6, 11080 Zemun-Belgrade, Serbia; dajic@agrif.bg.ac.rs
}

\begin{abstract}
The current study investigated and compared phytochemical and antioxidant activity of fresh fruit and some traditional products of Rubus idaeus grown in mountain region of Serbia. The total organic acid, total sugar content, total phenolics, flavonoids, tannins, anthocyanins and vitamin $\mathrm{C}$ were evaluated. The antioxidant activities were evaluated using two antioxidant systems 2,2-diphenyl-1-picrylhydrazyl (DPPH) and 2,2'-azinobis(3-ethylbenzothiazoline-6-sulfonic acid) (ABTS). The fresh fruit contained highest amount of vitamin $\mathrm{C}\left(46.62 \mathrm{mg} \mathrm{AA} \mathrm{g}^{-1}\right)$ and total organic acids $\left(882.22 \mathrm{mg} \mathrm{CA} \mathrm{g}^{-1}\right)$. The sweet preserve had highest content of total phenolics (200.83 mg GA g $\left.{ }^{-1}\right)$, flavonoids $\left(12.85 \mathrm{mg} \mathrm{RU} \mathrm{g}^{-1}\right)$ and tannins (39.11 $\left.\mathrm{mg} \mathrm{g}^{-1}\right)$. The juice had the highest total anthocyanin content $\left(107.22 \mu \mathrm{g} \mathrm{mL}^{-1}\right)$ and total sugar content $\left(25^{\circ} \mathrm{Brix}\right)$. The best antioxidant activity in ABTS assay had juice $\left(\mathrm{IC}_{50}=4.87 \mu \mathrm{mol} \mathrm{TE} \mathrm{g}^{-1}\right)$, followed by sweet preserve $\left(\mathrm{IC}_{50}=5.14 \mu \mathrm{mol} \mathrm{TE}\right.$ $\left.\mathrm{g}^{-1}\right)$, almost identical to standard gallic acid. In the DPPH free radical scavenging assay, sweet fruit preserve showed significant better antioxidant activity $\left(\mathrm{IC}_{50}=41.27 \mu \mathrm{g} \mathrm{mL}^{-1}\right)$ compared to juice $\left(\mathrm{IC}_{50}=106.07 \mu \mathrm{g} \mathrm{mL}^{-1}\right)$ and fresh fruit $\left(\mathrm{IC}_{50}=294.79 \mu \mathrm{g}\right.$ $\mathrm{mL}^{-1}$ ). Our results indicated promising perspectives for usage of $R$. idaeus fresh fruits and traditional products studied with considerable levels of vitamin $\mathrm{C}$, bioactive compounds and antioxidant activity.
\end{abstract}

Keywords: antioxidant activity; fruit; juice; phytochemical; sweet preserve

\section{Introduction}

The Rubus idaeus L. (red raspberry) together with about 750 species of the Rubus genus belongs to Rosaceae family (Alice and Campbell, 1999). The wild raspberry is a perennial shrub with a height of between $100 \mathrm{~cm}$ and 150 $\mathrm{cm}$. The stem is erect, cylindrical, and greyish, with a number of small thorns on the surface. The leaves are pinnate of 5-7 leaflets or sometimes 3, glabrous on the surface and very hairy on the abaxial side. The terminal leaflet is oblong or ovate and shallowly lobed, whereas stipules are fibrous or hairy. The cyme inflorescences are made of flowers that are usually lying down, composed of narrow white, glabrous and whitish petals. The fruit is pale pink or light orange (Tatić, 1972). In Serbia, the wild raspberry can usually be found on slopes, fires, spawns and spurs of beech and other forests, near streams and rivers, at an altitude of 600 to 1200 meters. Raspberry plant requires a lot of light and moisture.

The fruits have been used in traditional and alternative medicine for a long time to cure wounds, colic, diarrhea, and renal illnesses (Zhang et al., 2011). In addition, the red raspberry is an economically important berry crop that contains many phenolic compounds with potential health benefits. raspberry can be used in fresh or frozen as well as for processing: juice, syrup, wine, natural liqueur, compote, sweet, jam, ice cream, candied fruit, raspberry powder and pulp (Pritts, 2003). The fruits are sweet and sour, very tasty, aromatic and easily digestible. Raspberry is a "honey plant" which contains $77.4-90.9 \%$ of water, $9.1-22.6 \%$ of total dry matter, 8.0 - $13.0 \%$ soluble matter. Total sugars have 3.4 $-6.9 \%$, of which glucose is $1.1-3.3 \%$, fructose is $1.3-3.4 \%$ 
566

and sucrose is $0.1-2.0 \%$. The $\mathrm{pH}$ is acidic, ranged $2.95-3.52$. Free organic acids have $1.4 \%$ (mostly citric acid, malic acid, formic acid and 2-Hydroxybenzoic acid). Vitamin $\mathrm{C}$ is comprised of about $25 \mathrm{mg} \%$.

During last two decade, the interest in consuming fresh fruits has been intensified, due to its content of bioactive nutrients and their importance as food antioxidants. The phytochemicals such as flavonoids and phenolic acids are the most common phenolic compounds with antioxidant activity and may help protect cells against the oxidative damage caused by free radicals (Wada and Ou, 2002). In animal studies involving breast, cervical, colon, esophageal, and prostate cancers, raspberry phytophemicals have been shown to play an important role in lowering oxidative stress, reducing inflammation, and thereby altering the development or reproduction of cancer cells. Among flavonoids, quercetin, kaempferol and myricetin as well as their derivatives (primarily glycosides), may provide health benefits as dietary antioxidants (Siriwoharn et al., 2004). Phenolic acids constitute about one-third of the dietary phenols (Zadernowski et al., 2005), and raspberry is considered to be among the fruits with considerable amount of ellagic acid (Koponen et al., 2007). Most notably, the anthocyanins cyanidin-3-sophoroside, cyanidin-3- $(2(\mathrm{G})-$ glucosylrutinoside) and cyaniding-3-glucoside, the two ellagitannins sanguiin H-6 and lambertianin $\mathrm{C}$ are present together with trace levels of flavonols, ellagic acid and hydroxycinnamate (Mullen et al., 2002).

Although literature provides a lot of data about phytochemical composition and the antioxidant activity of raspberries from different cultivation sites, detailed information about wild $R$. idaeus grown in Serbia and other countries is still missing. Hence, the current study was designated with aim to investigate the phytochemical and antioxidative potential of fresh fruits and traditional products such as juice and sweet preserve. The obtained results can be useful in clarifying the quality of fruits and traditional products in order to their promotion and application as food additive and nutraceutical.

\section{Materials and Methods}

\section{Plantmaterial}

Plant material (Rubus idaeus L.) was collected from mountain region of 'Golija', Serbia (43.19140735N, 20.25105463E, and $1432.0 \mathrm{~m}$ ). Plant sample has been deposited at Department of Applied Botany at Faculty of Agriculture, Belgrade and were checked by Prof. Dajić Stevanović.

Fruits of wild raspberry were collected in middle JulyAugust, 2016 at full maturity stage suitable for human diet and preparation of selected nutritional products. Sampling involved 30 individuals from study site. After harvesting, 10 $\mathrm{kg}$ of fresh fruits were stored at $-20^{\circ} \mathrm{C}$ for maximum of one week prior to conducting chemical analysis.

The quantification of total phenolics, flavonoids, tannins, anthocyanins, free organic acids, sugar content, and L-ascorbic acid as well as antioxidant capacity were measured by $\mathrm{ABTS}^{*+}$ and $\mathrm{DPPH}^{+}$methods in order to compare the quality of fresh fruits and selected traditional products.
Preparation of fresh fruit extract and traditional products

The fruits $(10 \mathrm{~g})$ were mixed with $20 \mathrm{~mL} 80 \%$ methanol and homogenized in blander. The obtained mixture was transferred into Erlenmeyer bottle and stored at room temperature for 24 hours in dark. After that, the extract was filtered through a filter paper (Watman No. 1) and residues were re-extracted by same solvent for tree times and obtained fractions were collected. The portions of the sample were transferred in vials and used for phytochemical analyses and determination of antioxidant capacity.

The selected products, traditional Balkan fruit sweet preserve ("slatko" in Serbian) and juice were prepared according to following procedure. For preparation fruit sweet preserve $1 \mathrm{~kg}$ of wild raspberry fruit was mixed with 1 $\mathrm{kg}$ of sugar and $200 \mathrm{~mL}$ of water. The mixture was cooked on the temperature of $80-90^{\circ} \mathrm{C}$ for $20 \mathrm{~min}$. When the cooking was finished, fruit preserve was covered with a wet cloth and was left overnight to cool down before it was put into the glass jars. Traditional juice (syrup) was prepared by crushing of the fresh fruits $(1 \mathrm{~kg})$, transferred into Erlenmeyer bottle $(1 \mathrm{~L})$ and left overnight. Day after the prepared mixture was filtered through the double gauze and then $1 \mathrm{~kg} \mathrm{~L}^{-1}$ of sugar was added. The product was stirred occasionally during next 2-3 days until the sugar was completely dissolved and then poured into the glass bottles. The samples of juice and sweet preserve used for phytochemical analyses and antioxidant activity were prepared according to procedure described for fresh fruits.

Determination of physico-chemical parameters

Determination of free organic acids and total sugar contents

Concentration of free organic acids was determined by volumetric method (Horwitz, 1975). To $10 \mathrm{~mL}$ (g) of extract (fresh fruits, juice and "slatko") was added $50 \mathrm{~mL}$ of ethanol $(70 \%)$ and reaction mixture was incubated at $70{ }^{\circ} \mathrm{C}$ in water bath for $1 \mathrm{~h}$. The mixture was filtered through Whatman filter paper No. 1 and filtrate was concentrated at 50-60 ${ }^{\circ} \mathrm{C}$ under reduced pressure to the final extract volume of $40 \mathrm{~mL}$. Active charcoal was added to extract following by incubation ( 30 to $45 \mathrm{~min}$ ) in the water bath at $70{ }^{\circ} \mathrm{C}$. After incubation, the extract was filtrated to remove active charcoal; the residue was made up to a volume of $100 \mathrm{~mL}$ with distilled water. Ten millilitres aliquots of filtrate were sampling for determination of concentration the free organic acids by titration with $0.1 \mathrm{M} \quad \mathrm{NaOH}$. Phenolphthalein $(0.1 \%)$ was used as indicator. The results were presented as mg citric acid $100 \mathrm{~g}^{-1}$ fw.

Total sugar content was determined by the refractometric method, using an Abbe refractometer (Model RMT, Optech, Italy) (Bartolomé et al., 1995). A refractometer measures TSS as ${ }^{\circ}$ Brix (percent sucrose by weight), in $0.1 \%$ graduations.

\section{Determination of phenolic and L-Ascorbic acid contents Total phenolic content}

The total phenolic content in the extracts was determined according to the Folin-Ciocalteu method by Wootton-Beard et al. (2011) with slight modifications. The reaction mixture was prepared by mixing $0.5 \mathrm{~mL}$ of methanolic solution of the extract $\left(1 \mathrm{mg} \mathrm{mL}^{-1}\right), 2.5 \mathrm{~mL}$ of 
$10 \%$ water-soluble Folin-Ciocalteu reagent and $2.5 \mathrm{~mL}$ $7.5 \% \mathrm{NaHCO}_{3}$. The samples were then incubated at $45^{\circ} \mathrm{C}$ for $15 \mathrm{~min}$. Blank was prepared in the same way, only methanol was added instead of the extract. The absorbance of the samples and the blank was measured on the spectrophotometer at $\lambda_{\max }=765 \mathrm{~nm}$ (Jenway 6105; Bibby Scientific Limited, Staffordshire, UK). The same procedure was repeated for gallic acid (GA) to calculate the equivalent concentration of total phenols ( $\mathrm{mg}$ of $\mathrm{GA} \mathrm{g}^{-1} \mathrm{fw}$ ).

\section{Total flavonoid content}

The aluminum chloride method was used for the determination of the total flavonoids content of the extracts (Brighente et al., 2007). The samples were prepared by mixing $1 \mathrm{~mL}$ of the methanolic solution of the extract $(1 \mathrm{mg}$ $\mathrm{mL}^{-1}$ ) and $1 \mathrm{~mL}$ of $2 \% \mathrm{AlCl}_{3}$ dissolved in methanol. The samples were incubated for an hour at room temperature. The absorbance was measured spectrophometrically at $\lambda_{\max }$ $=415 \mathrm{~nm}$. The same procedure was repeated for rutin (RU) to calculate the equivalent concentration of flavonoids $(\mathrm{mg}$ of $\mathrm{RU}^{-1} \mathrm{fw}$ ).

\section{Total tannins content}

The total amount of tannins was determined by spectrometry measurement (Hosu et al., 2014). The samples were prepared by mixing $2 \mathrm{~mL}$ of the extract, $3 \mathrm{~mL}$ of concentrated $\mathrm{HCl}$ and $1 \mathrm{~mL}$ of distilled water. The content of the first sample was incubated for $30 \mathrm{~min}$ at 100 ${ }^{\circ} \mathrm{C}$ whereas $0.5 \mathrm{~mL}$ of ethanol was added to the second sample. The absorbance of the samples was determined spectrophometrically at $\lambda_{\max }=470,520$ and $570 \mathrm{~nm}$. The differences $(\Delta \mathrm{A})$ between the samples values obtained were determined at the same wavelengths $(\triangle \mathrm{A} 470, \Delta \mathrm{A} 520$, $\Delta \mathrm{A} 570)$. The values for wavelengths $\Delta \mathrm{A} 470, \Delta \mathrm{A} 520$ and $\Delta \mathrm{A} 570$ were calculated as follows: TTC $\left(\mathrm{g} \mathrm{L}^{-1}\right)=15.7 \times$ minimum $(\triangle \mathrm{A} 520)$.

\section{Anthocyanins content}

Samples containing $0.5 \mathrm{~mL}$ of extract, $0.5 \mathrm{~mL}$ of $0.1 \%$ ethanolic - $\mathrm{HCl}$ solution and $10 \mathrm{~mL}$ of $2 \%$ aqueous - $\mathrm{HCl}$ solution were used to determine the total anthocyanins content (Hosu et al., 2014). The procedure was as follows: $4.4 \mathrm{~mL}$ of distilled water was added to the first sample, while $4.4 \mathrm{~mL}$ of $13 \%$ sodium bisulphate was added to the second sample and diluted at a ratio of 1:1. The absorbance of the samples was determined at a wavelength of $\lambda_{\max }=520 \mathrm{~nm}$ using a starting solution made up of $4.9 \mathrm{~mL}$ distilled water, $0.5 \mathrm{~mL}$ of $0.1 \%$ ethanolic- $\mathrm{HCl}$ solution and $10 \mathrm{~mL}$ of $2 \%$ aqueous - $\mathrm{HCl}$ solution. The values obtained $(\Delta \mathrm{A})$ were multiplied by the coefficient 875 . The total amount of anthocyanins in a sample is expressed in $\mu \mathrm{g} \mathrm{mL}^{-1}$ of fw.

\section{$L$-ascorbic acid content}

Analysis of ascorbic acid was performed as described in protocol by Stevens et al. (2007). Fruits were grounded in liquid nitrogen and conserved at $-80{ }^{\circ} \mathrm{C}$ until analysis. Around $500 \mathrm{mg}$ of grounded raspberry fruits were homogenized in $2 \mathrm{ml}$ tubes with $600 \mu \mathrm{l}$ of $6 \%$ trichloroacetic acid (TCA). During this process, it was paid attention that powder does not melt at any time of preparation. Afterwards, the tubes were shaken in grinder for one minute and then put on vortex for $20 \mathrm{~s}$. The next step was centrifugation $\left(15 \mathrm{~min}, 4{ }^{\circ} \mathrm{C}, 13,200 \mathrm{rpm}\right)$. Supernatant was used for further analysis. For each sample two assays were carried out: one to measure total acrobat (including the addition of DTT) and one to measure reduces acrobat content (omission of DTT from the assay). After addition of DTT (total acrobat assay) and phosphate buffer (reduced ascorbate assay), the 96-micro-well plate was incubated at $37^{\circ} \mathrm{C}$ for $20 \mathrm{~min}$. In wells with DTT was added $10 \mu \mathrm{L}$ of $\mathrm{N}$-ethylmalemide. In each well was added 80 $\mu \mathrm{L}$ of coloring reagent. The coloration agent consisted of a mixture of two solutions. Preparation A was composed of $18 \mathrm{~mL}$ ortho-phosphoric acid (85\%), $31.5 \mathrm{~mL}$ ultrapure water, $2.3 \mathrm{~g}$ trichloroacetic acid and $0.3 \mathrm{~g}$ ferric chloride $\left(\mathrm{FeCl}_{3}\right)$. Preparation B was a dilution of $2.0 \mathrm{~g}$ 2,2-Bipyridyl in $50 \mathrm{~mL}$ of ethanol (70\%). $6.6 \mathrm{~mL}$ of preparation $\mathrm{A}$ and $2.4 \mathrm{~mL}$ of preparation $\mathrm{B}$ were combined imminently before analysis due to instability of the mixture. $80 \mu \mathrm{L}$ of the coloration agent was placed in each well to start the coloration reaction. The micro-plate was then placed in the micro-plate reader where it was agitated and kept for complete reaction during $50 \mathrm{~min}$ at $37^{\circ} \mathrm{C}$. Absorbance was measured at a wavelength of $525 \mathrm{~nm}$. Commercial Lascorbic acid was used to generate the standard curve.

\section{In vitro antioxidant activity assays}

\section{$D P P H$ free radical scavenging assay}

For the estimation of anti-radical potential, DPPH free radical scavenging activity of all the extracts was conducted using DPPH method (Takao et al., 1994). Working solution of extracts was carried out by dilution stock solution $\left(2 \mathrm{mg} \mathrm{mL}^{-1}\right)$ of extracts. DPPH was dissolved in methanol to obtain a concentration at $8 \mu \mathrm{g} \mathrm{mL} L^{-1}$. To $1 \mathrm{~mL}$ of DPPH solution, $1 \mathrm{~mL}$ of various concentrations of the extracts or the standard solution was added separately. The reaction mixtures were incubated at $37{ }^{\circ} \mathrm{C}$ for $30 \mathrm{~min}$, following by absorbance measured at $517 \mathrm{~nm}$ using methanol as blank reference. The DPPH scavenging activity (\%) of extracts and standards AA, gallic acid (GA), butylated hydroxytoluene (BHT), $\alpha$-tocopherol, quercetin was determined using the following equation (1):

$$
\text { \%inhibition }=[(\text { Ac-As }) / A c] \times 100
$$

Where Ac was absorbance of control reaction and As the absorbance in presence of the sample.

\section{2,2'-azino-di(3-ethylbenzthiazoline-6-sulfonic acid) (ABTS) decolorization assay}

The $\mathrm{ABTS}^{\circ+}$ radical cation decolorization assay is spectrophotometric method widely used for determination of the antioxidative activity of substances. The ABTS ${ }^{+}$ scavenging activity was measured according to procedure described in work of Jakovljević et al. (2016). In brief, the $\mathrm{ABTS}^{\bullet+}$ radical cation was first produced by reacting ABTS stock solution $(7 \mathrm{mM})$ with potassium persulfate $(2.45$ $\mathrm{mM})$. The mixture was then placed in the dark at room temperature for 12 to $16 \mathrm{~h}$ before using. Under this condition, $\mathrm{ABTS}^{*+}$ can be stable in this form for more than 2 days. The $\mathrm{ABTS}^{\circ+}$ solution was diluted with doubledistilled water to obtain an absorbance of $0.70 \pm 0.02$ at 734 $\mathrm{nm}$. Aliquots of $30 \mu \mathrm{L}$ of the sample extracts different 
568

concentrations (from $2 \mathrm{mg} \mathrm{mL}^{-1}$ to $3.91 \mu \mathrm{g} \mathrm{mL}^{-1}$ ) were then added to $2.7 \mathrm{~mL}$ diluted $\mathrm{ABTS}^{\circ+}$ solution, and mixture was incubated at room temperature for $30 \mathrm{~min}$. Absorbance was determined spectrophometrically at $734 \mathrm{~nm}$. For the control, $1.0 \mathrm{~mL}$ of methanol was used instead of extract. AA, GA, chlorogenic acid (GCA), protocatechuic acid (PCA), and beta-resorcylic acid (BRA) were used as standards. The percentage of inhibition was calculated using the Eq. (1) and results are expressed as $\mathrm{IC}_{50}$ value.

\section{Statistical analysis}

Statistical analyses were performed with the software packages SPSS for Windows (version 17.0). All measurements were carried out in triplicate, and the results are presented as mean \pm S.E.M. Statistical analysis was performed via Pearson's correlation coefficient, as well as, ANOVA, followed by the Tukey HSD test which was used to test the differences in quality parameters (the content of organic acids, total sugar and ascorbic acid).

\section{Results and Discussion}

The total sugars and organic acids content have significant impact on fruit flavor and quality. Due to, the total organic acids (total acidity), total sugar and ascorbic acid content in fresh fruit, juice and sweet fruit preserve of $R$. idaeus from Serbia were examined (Table 1). As the Table shows, the fresh fruit sample had a considerable amount of TOA (882.22 $\left.\mathrm{mg} \mathrm{CA} \mathrm{g}^{-1} \mathrm{fw}\right)$. Previous findings on the amount of organic acid in the raspberry fruits are obtained by testing the different raspberry cultivars growing in different region, but only one study investigated the $R$. idaeus and two cultivars from Serbia. Milivojević et al. (2011) found significant lower amount of organic acids in fruits of $R$. idaeus and cultivars 'Willamatte' and 'Meeker' from Serbia (0.15 $\mathrm{mg} \mathrm{CA} \mathrm{g}^{-1} \mathrm{fw}, 0.24 \mathrm{mg} \mathrm{CA} \mathrm{g}^{-1} \mathrm{fw}$ and 0.18 $\mathrm{mg} \mathrm{CA} \mathrm{g}^{-1}$ fw, respectively). Gulcin et al. (2011) revealed titratable acidity of domesticated and three wild ecotypes of raspberry fruits (from Coruk region, Turkey) in amount of $1.35 \%$ and $1.05-1.11 \%$, respectively. Tamer (2012) found that the total acidity of four raspberry cultivars (from Bursa,

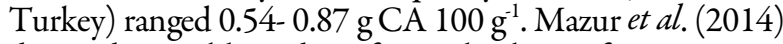
detected titratable acidity of several cultivars from Western

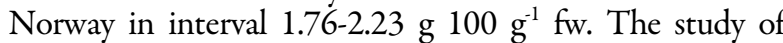
Zorenc et al. (2017) showed that two raspberry cultivars 'Amira' and 'Polka' (from Slovenia) had the TOA content of 20.2 and $19.9 \mathrm{mg} \mathrm{g}^{-1} \mathrm{fw}$. Comparing the current result with above-mentioned it can be concluded that tested $R$. idaeus fruits from Serbia is much better source of organic acids than mentioned raspberry cultivars. According to statement of Poyrazoğlu et al. (2002) the differences in the organic acidity content between raspberry fruits might have arisen from genetic factors, climatic factors, and/or cultural practices. In the case of traditional product prepared from fruits, such as juice and sweet fruit preserve, the current study showed that both of them had significantly lower amount of TOA (396.29 and $250.73 \mathrm{mg} \mathrm{CA} \mathrm{g}^{-1}$ fw respectively) than fresh fruits. The obtained results could be explained by addition of sugar (sucrose) during their processing. This is opposite to results of Tamer (2012) who revealed an increase in total acidity content (about 2- to 3fold) in samples of marmalade prepared from raspberry cultivars. The author was explained these results by addition of citric acid during marmalade preparation.

Beside organic acids, sugars also have a significant impact on the sensory quality and flavor of the fruit (Wang et al., 2009). The highest amount of total sugar was found in the juice (25.74 ${ }^{\circ}$ Brix), followed by in fruit preserve (16.12 $\left.{ }^{\circ} \mathrm{Brix}\right)$, and at least in fresh fruit sample $\left(7.02^{\circ} \mathrm{Brix}\right)$ (Table 1). The existence of a significantly higher TSC in traditional products than in fresh fruits could be explained by adding the sucrose during preparation of products. The study of Milivojević et al. (2011) revealed small amount of sucrose in R. idaeus, 'Willamatte' and 'Meeker' (from Serbia) $(6.9 \mathrm{mg}$ $\mathrm{g}^{-1} \mathrm{fw}, 6.4 \mathrm{mg} \mathrm{g}^{-1} \mathrm{fw}$ and $5.3 \mathrm{mg} \mathrm{g}^{-1} \mathrm{fw}$ ). According to the literature data (Mikulić-Petkovsek et al., 2012), the wild raspberry fruit grown in Slovenia had some higher TSC than tested fruit sample. In addition, the two cultivars ('Amira' and 'Polka') from Slovenia had higher TSC (34.3 $\mathrm{mg} \mathrm{g}^{-1} \mathrm{fw}$ and $31.9 \mathrm{mg} \mathrm{g}^{-1} \mathrm{fw}$ ) than current $R$. idaeus fruits. Gulcin et al. (2011) found total soluble sugars in amount of $15.56 \%$ in domesticated and $19.58-22.03 \%$ in three wild ecotypes of raspberry fruits (from Coruk region, Turkey). As in the case of organic acids, these differences could be explained by different environment conditions: light exposure, growing of plants on open, sunny and warmer habitats (Wang et al., 2009). Fruits from plant individuals, which grew in conditions of low light intensity, have lower sugar content.

The concentration of Vitamin C (AA) found in fresh fruit sample was $46.62 \mathrm{mg} 100 \mathrm{~g}^{-1}$ (Table 1). Based on results found in literature (Mapson, 1970), this value is approximately 2-fold higher than the usual amount of AA found in raspberry fruits $\left(25 \mathrm{mg} 100 \mathrm{~g}^{-1} \mathrm{fw}\right)$. The obtained result is similar to data recorded for wild raspberries fruit growing in Macedonia (Karakashova et al., 2012), as well as for cultivated varieties from the territory of Norway (17.4 mg AA $100 \mathrm{~g}^{-1} \mathrm{fw}$ - $46.9 \mathrm{mg} \mathrm{AA} 100 \mathrm{~g}^{-1} \mathrm{fw}$ ) (Mazur et al., 2014). Pantelidis et al. (2007) reported that cultivated raspberry varieties are also a rich source of AA. Our results on $R$. idaeus fresh fruits are in line with previous studies showing that berries are an important source of vitamin $C$.

Table 1. The content of organic acids, total sugar and ascorbic acid in Rubus ideaus samples

\begin{tabular}{|c|c|c|c|}
\hline Samples & $\begin{array}{c}\text { AA } \\
\left(\mathrm{mg} 100 \mathrm{~g}^{-1} \mathrm{fw}\right)\end{array}$ & $\begin{array}{c}\text { TSC } \\
\left({ }^{\circ} \text { Brix }\right)\end{array}$ & $\begin{array}{c}\text { TOA } \\
\left(\mathrm{mg} \mathrm{CAg} \mathrm{g}^{-1} \mathrm{fw}\right)\end{array}$ \\
\hline Fruits & $46.62 \pm 2.25^{a}$ & $7.02 \pm 0.04^{\mathrm{a}}$ & $882.22 \pm 24.15^{a}$ \\
\hline Juice (syrup) & $9.73 \pm 1.12^{\mathrm{b}}$ & $25.74 \pm 1.48^{b}$ & $396.29 \pm 16.11^{b}$ \\
\hline Sweet fruits preserve & $4.25 \pm 0.15^{c}$ & $16.12 \pm 1.55^{\mathrm{c}}$ & $250.73 \pm 10.33^{c}$ \\
\hline
\end{tabular}


However, it is important to note that the current result is significantly better compared to amount AA found in fresh raspberries (7.60 to $18.11 \mathrm{mg} 100 \mathrm{~g}^{-1}$ ) cultivated in Bursa (Turkey) (Tamer, 2012). Gulcin et al. (2011) found very low amount of AA in wild $\left(2.4 \mathrm{mg} \mathrm{kg}^{-1}\right)$ and domesticated raspberry fruits $(5.34 \mathrm{mg} \mathrm{kg})$. The concentration of AA in traditional products prepared from fresh fruits i.e. juice and sweet fruit preserve was ranged

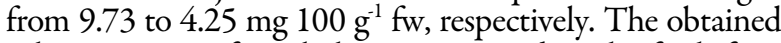
values were significantly lower compared to the fresh fruit sample. This observation is in accordance with findings of other researchers. Tamer (2012) revealed that AA content in raspberry marmalade was lower than in fresh fruit of different raspberry cultivars. Depending from cultivars, its

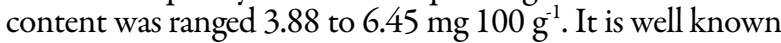
that AA is a thermolabile compound (Rauha et al., 2000), so in the juice, the AA concentration decreased 4.8-fold and in the sweet fruit preserve for 10.9-fold. The thermal degradation of vitamin $\mathrm{C}$ had strong temperature dependent. The best temperature for minimizing reduction of water-soluble vitamins is $70^{\circ} \mathrm{C}$ (Kadakal et al., 2017).

Many researchers revealed that berry fruits are great dietary sources of bioactive compounds (phenolic compounds such as phenolic acids, flavonoids-flavonols, anthocyanins, tannins, and ascorbic acid). These compounds may act as strong antioxidants and, thus, could help in the prevention of many diseases (Skrovankova et al., 2015). The current study showed that fresh fruit of $R$. idaeus growing in Serbia contained the TPC value of 362.30 mg GAE $100 \mathrm{~g}^{-1} \mathrm{fw}$ (Table 2) which is in agreement with other studies. Literature revealed many results of TPC obtained with Folin-Ciolcateu reagent for raspberry fruits. Wang and Lin (2000) showed that TPC ranged from 208 to $268 \mathrm{mg}$ GAE $100 \mathrm{~g}^{-1} \mathrm{fw}$ in red raspberries. Similar content of total phenolics was confirmed by Mazur $e t$ al. (2014) in fruits of several cultivars from Norway (183.1 $287.7 \mathrm{mg}$ GAE $100 \mathrm{~g} \mathrm{~g}^{-1} \mathrm{fw}$ ). Mikulić-Petkovsek et al. (2012) revealed that wild grown raspberry (from Slovenia) contained $223.2 \mathrm{mg} \mathrm{GA} \mathrm{kg}{ }^{-1}$ fw compared to cultivated raspberry which contained $107.6 \mathrm{mg} \mathrm{GA} \mathrm{kg}^{-1} \mathrm{fw}$. Pantelidis and co-workers (2007) reported that 50\%-methanolic extracts of fruits of a few raspberry cultivars grown in Greece contained between 1052 and $2494 \mathrm{mg} \mathrm{GAE} 100 \mathrm{~g}^{-1} \mathrm{dw}$. According to work of Bobinaite et al. (2012) the TPC values of methanolic extracts of raspberries from Lithuania ('Pokusa' and 'Bristol') varied from 278.6 to $714.7 \mathrm{mg} \mathrm{GAE}$ $100 \mathrm{~g}^{-1} \mathrm{fw}$. Chen and co-workers (2013) showed the TPC values of $0.1 \%(\mathrm{v} / \mathrm{v})$ methanolic extract of raspberries (grown in northern China) were 215.54 to $619.35 \mathrm{mg} 100$ $\mathrm{g}^{-1}$ fw. Kostecka-Gugala et al. (2015) revealed the TPC, expressed as chlorogenic acid equivalents, in red raspberry fruits (cv. 'Sokolica' and 'Laszka') in amount of 175.90 in seasons 2013, to $549.02 \mathrm{mg} 100 \mathrm{~g}^{-1} \mathrm{fw}$ in season 2012. Sariburun et al. (2010) observed the TPC in water and methanolic extracts of several raspberry cultivars (from Turkey) in amount of 1040.9-1822.0 mg GAE $100 \mathrm{~g}^{-1} \mathrm{fw}$, and 1787.3-2062.3 mg GAE $100 \mathrm{~g}^{-1} \mathrm{fw}$, respectively.

With regard to TPC, the juice and sweet fruit preserve samples contained 108.30 and $200.83 \mathrm{mg} \mathrm{GAE} 100 \mathrm{~g}^{-1} \mathrm{fw}$, respectively. These values are significantly higher compared to fresh fruits, which could be explained by processing operations. However, most of the literature data about antioxidants of fruits, vegetables, and grains have shown that food processing operations reduced the antioxidants of the processed foods. Rickman et al. (2007) and Serrano et al. (2011) found that some of the phenolic compound was decreased in thermal processing. Le Bourvellec et al. (2018) revealed that thermal processing could cause significant reduction in chemical composition of foods including phenolic compounds and antioxidant activities. Hassani $e t$ al. (2015) observed the mean decrease percentage of ellagic acid, total flavonoids, total polyphenols as well as antioxidant activity after jam processing. Van Boekel $e t$ al. (2010) reported that cooking of vegetable causes the breakage of cell wall component and subsequent release of molecules and cause the leaching of water-soluble polyphenol into the surrounding water or may destroy polyphenols by high temperature. Nevertheless, positive effect of thermal processing/cooking on amount of TPC is also reported in literature. Processing and heating during jam making (at 104-105 ${ }^{\circ} \mathrm{C}$ ) reduces the TPC of some varieties of cherries and plums, whereas no significant change occurred in raspberries, plums, and some varieties of cherries (Kim and Padilla-Zakour, 2004). Sablani et al. (2010) reported that canning of raspberries $\left(100{ }^{\circ} \mathrm{C}, 28\right.$ minutes) and blueberries $\left(100^{\circ} \mathrm{C}, 22\right.$ minutes) increases the phenolic content and antioxidant activity by $50 \%$ and $53 \%$, respectively.

The TFC measured in fruit, juice and sweet fruit preserve was $4.93,9.25$ and $12.85 \mathrm{mg} \mathrm{RU} \mathrm{g}^{-1}$ fw, respectively (Table 2). Similar to TPC, the TFC was 2-fold and 3-fold higher in juice and sweet fruit preserve compared to fresh fruit. The obtained result for fresh fruit is in good agreement with previous findings. Gulcin et al. (2011) showed the TFC in domesticated and wild raspberry fruits (Coruk region, Turkey) were 2.62 and 1.77-6.09 QE, respectively. The study of Sariburun et al. (2010) revealed that water and methanolic extracts of five raspberry cultivars (from Turkey) possessed TFC in amount of $15.4-41.3 \mathrm{mg}$ CTE $100 \mathrm{~g}^{-1} \mathrm{fw}$, which is much higher compared to tested $R$. idaeus fruits from Serbia.

The TAC determined in fruits, juice and sweet fruits preserve samples was $4.73,107.22$ and $106.67 \mathrm{mg} \mathrm{mL}^{-1}$ respectively (Table 2 ).

Table 2. The content of phytochemicals in $R$. idaeus samples

\begin{tabular}{|c|c|c|c|c|}
\hline Sample & $\begin{array}{c}\text { TPC } \\
(\mathrm{mg} \mathrm{GA} / \mathrm{g})\end{array}$ & $\begin{array}{c}\text { TFC } \\
(\mathrm{mg} \mathrm{RU} / \mathrm{g})\end{array}$ & $\begin{array}{c}\text { TTC } \\
(\mathrm{mg} / \mathrm{mL})\end{array}$ & $\begin{array}{c}\text { TAC } \\
(\mu \mathrm{gTA} / \mathrm{mL})\end{array}$ \\
\hline Fruit & $36.23 \pm 0.43^{a}$ & $4.93 \pm 0.27^{a}$ & $0.40 \pm 0.017^{\mathrm{a}}$ & $4.73 \pm 0.35^{a}$ \\
\hline Juice (syrup) & $108.83 \pm 0.67^{b}$ & $9.25 \pm 0.12^{b}$ & $36.71 \pm 0.391^{b}$ & $107.22 \pm 1.77^{\mathrm{b}}$ \\
\hline Sweet fruit preserve & $200.83 \pm 2.64^{c}$ & $12.85 \pm 0.22^{\mathrm{c}}$ & $39.11 \pm 0.953^{\mathrm{c}}$ & $106.67 \pm 1.42^{\mathrm{b}}$ \\
\hline
\end{tabular}


570

According to Kostecka-Gugala et al. (2015), the TAC among red raspberries ranged from 29.69 ('Sokolica', season 2013 ) to $81.13 \mathrm{mg}$ ('Willamette', season 2012). The TAC in red raspberries, expressed also as cyanidin 3-glucoside equivalents per $100 \mathrm{~g} \mathrm{fw}$, varied from 45.4 to $99.5 \mathrm{mg}$ (Wang and Lin, 2000) and from 35.1 to $49.1 \mathrm{mg}$ (Pantelidis et al., 2007). Koponen and co-workers (2007) concluded that TAC was typically below $100 \mathrm{mg} 100 \mathrm{~g}^{-1} \mathrm{fw}$ in red raspberries, regardless the method or cultivar. The EtOHwater extracts from varieties of $R$. idaeus ('Ljulin', 'Veten') was studied by Krauze-Baranowska et al. (2014) and it was found TAC of 1328.2 and $889.1 \mathrm{mg} 100 \mathrm{~g}^{-1} \mathrm{dw}$. The fruits of $R$. idaeus 'Ljulin' contained cyanidin 3-O-sophoroside as the main anthocyanin, while in the fruits of the 'Veten' variety, cyanidin 3-O-glucoside, cyanidin 3-O-rutinoside and cyanidin 3-O-sophoroside were the dominating cyanidin glycosides (Krauze-Baranowska et al., 2014). The study of Sariburun et al. (2010) showed that water and methanolic extracts of raspberry cultivars from Turkey contained between 22.4 - $69.6 \mathrm{mg}$ cyn-3-glu $100 \mathrm{~g}^{-1} \mathrm{fw}$ and 16.3 - $34.8 \mathrm{mg}$ cyn-3-glu $100 \mathrm{~g}^{-1}$ fw, depending from solvent type.

The results of the current study found TTC in all tested samples, in following order: fruit preserve $\left(39.11 \mathrm{mg} \mathrm{mL}^{-1}\right)$, juice $\left(36.71 \mathrm{mg} \mathrm{mL}^{-1}\right)$ and fresh fruit $\left(0.40 \mathrm{mg} \mathrm{mL}^{-1}\right)^{\circ}$ (Table 2). From obtained results, it is clear that fresh fruit sample contained about 100-fold lower amount of tannins compared to raspberry preserve and juice. Obtained results of Hussein et al. (2017) showed that $R$. idaeus fruit (from market of Sulaimanya city, North of Iraq) contain $853 \mu \mathrm{g} \mathrm{g}^{-1}$ of tannic acid, which is lower compared to current fresh fruit. Gasperotti et al. (2010) described two main raspberry ellagitannins: sanguiin H-6 and lambertianin C. It was found that the content of these compounds in fresh raspberry fruit, depending on the cultivar, ranges from 360 to $750 \mathrm{mg} \mathrm{kg}^{-1}$ for sanguiin $\mathrm{H}-6$ and from 280 to $630 \mathrm{mg} \mathrm{kg}$ ${ }^{1}$ for lambertianin C. The higher amount of TTC found in the juice and sweet preserve in relation to fresh fruit is in line with literature data. The increase in amount of free ellagic acid and stability of ellagic acid glicosides during processing and storage in raspberry jams has been reported by Amakura et al. (2001). In addition, Zafrilla et al. (2001) revealed an increase in amount of ellagic acid (about 2.5fold) during raspberries jam processing. Ellagic acid monomers are probably better absorbed than high molecular weight ellagitannins, and therefore jam processing could increase ellagic acid bioavailability.

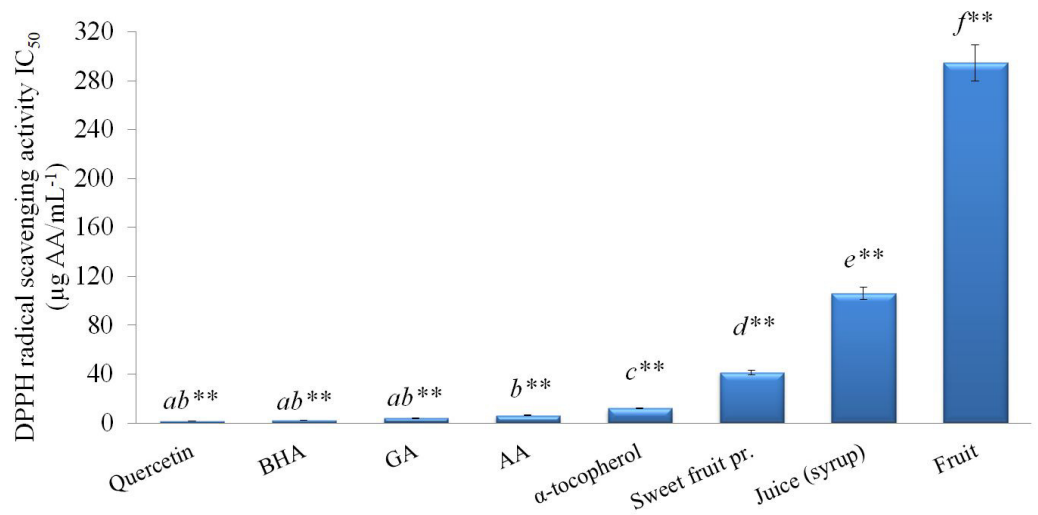

Fig. 1. Antioxidant activity ( $\mathrm{IC}_{50}$ values) of $R$. idaeus and some natural and synthetic antioxidants in DPPH assay

\section{Antioxidative potential of raspberry}

Measurement of antioxidant activity using in vitro assays is paramount in the evaluation of various food products and nutraceuticals for determining antioxidant benefits. The most popular and frequently used spectrophotometer methods for determining the antioxidant capacity in foods and chemical compounds are ABTS or DPPH methods (Kuskoski et al., 2005). Therefore, these two oxidant system were selected for the current study.

The DPPH antioxidant activity of fresh fruit, juice and sweet fruit preserve as well as some standards is presented in Fig. 1. In the DPPH free radical scavenging assay, sweet fruit preserve showed significant better antioxidant activity with $\mathrm{IC}_{50}=41.27 \mu \mathrm{g} \mathrm{mL}^{-1}$, compared to juice $\left(\mathrm{IC}_{50}=106.07 \mu \mathrm{g}\right.$ $\mathrm{mL}^{-1}$ ) and fresh fruit samples $\left(\mathrm{IC}_{50}=294.79 \mu \mathrm{g} \mathrm{mL}^{-1}\right)$. However, all samples had significant lower antioxidant activity in relation to tested standards. Tamer (2012) found that DPPH activity of fresh fruit extract $\left(0.3 \mathrm{mg} \mathrm{mL}^{-1}\right)$ ranged from $24.50 \%$ to $38.63 \%$. Sariburun et al. (2010) reported DPPH antioxidant activity of water and methanolic extracts of raspberry fruit cultivars (from Turkey) in range $64.14-89.13 \mu \mathrm{mol} \mathrm{TE} \mathrm{g}{ }^{-1} \mathrm{fw}$ and 81.17 $127.59 \mu \mathrm{mol} \mathrm{TE} \mathrm{g}^{-1} \mathrm{fw}$, respectively. Venskutonis et al. (2007) described the DPPH antioxidant activity of ethanolic extracts of 31 raspberry plants (from natural habitats of Lithuania) in range from $52.9-92.6 \%$. Bobinaite and co-workers (2012) found radical scavenging capacity of $57.9 \%$ in methanolic extract of raspberry fruit 'Meeker' (from Lithuania) Kostecka-Gugala et al. (2015) investigated fruits of several Polish cultivars of floricane and primocanefruiting red raspberry and found significant differences in DPPH antioxidant activity: $30.0-66.28 \%$ (in season 2012), and $28.05-56.89 \%$ (in 2013 vegetation period). The better antioxidant activity of sweet preserve and juice than fresh fruit is opposite to results found in literature. Veda $e t$ al. (2006) reported that heating and oxidation caused a decrease in the antioxidant activity. For example, antioxidant activity of marmalade significantly decreased and was in interval $1.79 \%$ to $12.11 \%$.

The ABTS antioxidant activity of fresh fruit, juice and sweet fruit preserve was in following order: $\mathrm{IC}_{50}=15.07$ $\mu \mathrm{mol} \mathrm{TE} \mathrm{g}{ }^{-1} \mathrm{fw}, \mathrm{IC}_{50}=4.87 \mu \mathrm{mol} \mathrm{TE} \mathrm{g} \mathrm{fw}^{-1}$ and $\mathrm{IC}_{50}=5.14$ $\mu \mathrm{mol}$ TE $\mathrm{g}^{-1} \mathrm{fw}$, respectively (Fig. 2.). The best antioxidant activity was observed in juice followed by in sweet preserve and fresh fruit sample. In relation to standards, the activity of juice and sweet preserve was in line with $\mathrm{GA}\left(\mathrm{IC}_{50}=4.33\right.$ $\mu \mathrm{mol} \mathrm{TE} \mathrm{g}^{-1} \mathrm{fw}$ ), about 4 - to 5 -fold better than activity of 


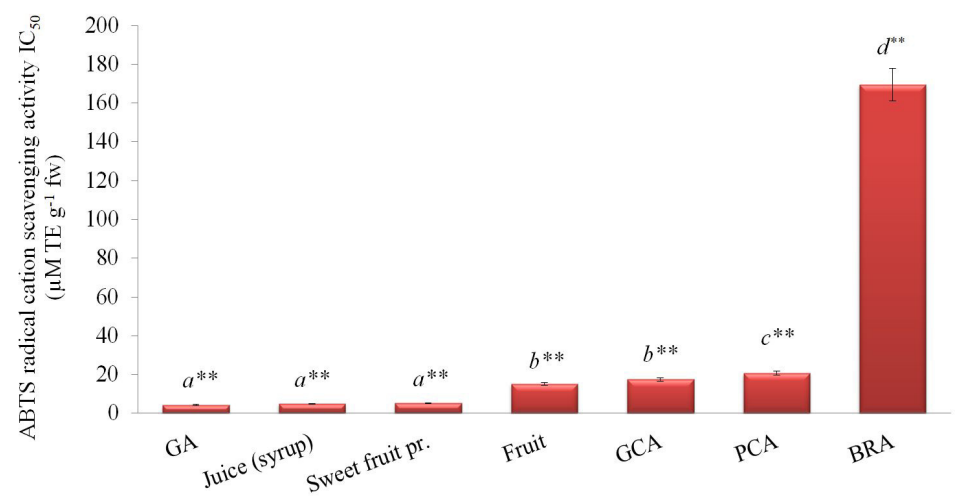

Fig. 2. Antioxidant activity ( $\mathrm{IC}_{50}$ values) of $R$. idaeus and some natural and synthetic antioxidants in $\mathrm{ABTS}$ assay

GCA $\left(\mathrm{IC}_{50}=17.23 \mu \mathrm{mol} \mathrm{TE} \mathrm{g}^{-1} \mathrm{fw}\right)$ and PCA $\left(\mathrm{IC}_{50}=20.66\right.$ $\left.\mu \mathrm{mol} \mathrm{TE} \mathrm{g} \mathrm{fw}^{-1}\right)$ and more than 100 -fold better than activity of BRA ( $\left.\mathrm{IC}_{50}=169.50 \mu \mathrm{mol} \mathrm{TE} \mathrm{g}^{-1} \mathrm{fw}\right)$. In addition, the current results are much better than those existing in literature. Milivojević et al. (2011) found antioxidant activity in ABTS assay for $R$. idaeus (1.41 $\mathrm{mg} \mathrm{AA} \mathrm{g}^{-1} \mathrm{fw}$ ), 'Willamatte' (3.20 $\mathrm{mg} \mathrm{AA} \mathrm{g}^{-1} \mathrm{fw}$ ) and 'Meeker' cultivar (1.32 $\mathrm{mg} \mathrm{AA} \mathrm{g}^{-1} \mathrm{fw}$ ) from Serbia. Sariburun et al. (2010) found that ABTS activity of water and methanolic extracts of raspberry cultivars (Turkey) ranged from 64.36 - 83.66 $\mu \mathrm{mol} \mathrm{TE} \mathrm{g}{ }^{-1}$ fw to 72.92-117.07 $\mu \mathrm{mol} \mathrm{TE} \mathrm{g}{ }^{-1}$ fw, respectively. Venskutonis et al. (2007) reported the radical scavenging activity of ethanolic extract of 31 raspberry plants (from Lithuania) in interval 52.5-97.8\%.

Çekiç and Özgen (2010) revealed antioxidant capacity of 8.9 to $21.5 \mu \mathrm{mol} \mathrm{TE} \mathrm{g}^{-1}$ fw for wild and cultivated red raspberries (Rubus ideaus L.) obtained at different altitude range.

\section{Statistical analysis}

Relationships among phytochemicals and antioxidant activity of fresh fruit sample and traditional products: juice and sweet preserve are presented in Table 3. The TPC was in a very strong positive correlation with TFC $\left(r=0.962^{* *}\right)$, TTC $\left(r=0.859^{* *}\right)$ and TAC $\left(r=0.827^{* *}\right)$ at $p<0.01$ level, in a two-tailed Pearson correlation. Similarly, strong positive correlation between TFA and TTC $\left(r=0.886^{*}\right)$ as well as between TFA and TAC $\left(r=0.861^{* *}\right)$ was found. However, the strongest correlation was found between TTC and TAC $\left(r=0.998^{* *}\right)$. The amount of Vitamin $C$ was in a very strong negative correlation with all tested phytochemicals, in following order: TTC $\left(r=-0.996^{*}\right)$, TAC $\left(r=-0.991^{* *}\right)$, TPC $\left(r=-0.890^{* *}\right)$ and TFC $\left(r=-0.899^{* *}\right)$. Antioxidant activity of samples studied in DPPH assay was in a very strong positive correlation with TOA $\left(r=0.999^{* *}\right)$, Vitamin $\mathrm{C}\left(r=0.990^{* *}\right)$ and TPC $\left(r=0.943^{* *}\right)$ and in negative correlation with TTC $\left(r=-0.980^{* *}\right)$, TAC $\left(r=-0.967^{* *}\right)$, TFC $\left(r=-0.943^{* *}\right)$ and TSC $\left(r=-0.673^{*}\right)$. In ABTS antioxidant assay, radical cation scavenging activity of samples was in positive correlation with TOA $\left(r=0.972^{* *}\right)$ and Vitamin $\mathrm{C}\left(r=0.980^{* *}\right)$ and in negative correlation with TTC and TAC $\left(r=-0.979^{* *}\right)$, TFC $\left(r=-0.884^{* *}\right)$, TTC $(r=$ $\left.-0.852^{* *}\right)$ and TSC $\left(r=-0.792^{*}\right)$.

Table 3. Linear correlation coefficients between phytochemicals and antioxidant capacities of Rubus idaeus

\begin{tabular}{|c|c|c|c|c|c|c|c|c|c|}
\hline & $\mathrm{TPC}^{\mathrm{a}}$ & $\mathrm{TFC}^{\mathrm{b}}$ & TTC $^{c}$ & $\mathrm{TAC}^{\mathrm{d}}$ & Vitamin C & $\mathrm{TOA}^{\mathrm{e}}$ & TSC $^{f}$ & $\mathrm{DPPH}^{\mathrm{g}}$ & ABTS $^{h}$ \\
\hline TPC & - & & & & & & & & \\
\hline TFC & 0.962 & - & & & & & & & \\
\hline TTC & $0.859^{\prime \prime}$ & $0.886^{\prime \prime}$ & - & & & & & & \\
\hline TAC & $0.827^{\prime \prime}$ & $0.861{ }^{*}$ & $0.998^{* \prime}$ & - & & & & & \\
\hline Vitamin C & $-0.890^{*}$ & $-0.899^{\prime \prime}$ & $-0.996^{*}$ & $-0.991 "$ & - & & & & \\
\hline TOA & -0.932 & $-0.940^{*}$ & -0.986 & 0.974 & $0.994^{*}$ & - & & & \\
\hline TSC & 0.392 & 0.471 & $0.803^{\prime \prime}$ & $0.838^{\prime \prime}$ & $-0.767^{\circ}$ & -0.696 & - & & \\
\hline DPPH & 0.943 & $-0.947^{*}$ & $-0.980 "$ & $-0.967^{*}$ & $0.990 "$ & $0.999 "$ & $-0.673^{\circ}$ & - & \\
\hline ABTS & $-0.852^{\circ \prime}$ & -0.884 & $-0.979^{*}$ & $-0.979^{*}$ & $0.980^{\circ}$ & 0.972 & $-0.792^{\circ}$ & $0.966^{\prime \prime}$ & - \\
\hline
\end{tabular}

${ }^{\mathrm{a}}$ Total phenolic contents, ${ }^{\mathrm{b}}$ total flavonoid contents, ${ }^{\mathrm{c}}$ total tannins, ${ }^{\mathrm{d}}$ total anthocyanins, ${ }^{\mathrm{e}}$ total organic acids, ${ }^{\mathrm{f}}$ total sugar content, ${ }^{\mathrm{g}}$ DPPH scavenger activity, ${ }^{\mathrm{h}}$ ABTS radical cation scavenger activity.

Pearson Correlation Sig. (2-tailed). "Correlation is significant at the 0.05 level. "Correlation is significant at the 0.01 level.

\section{Conclusions}

This is the first study focused on the comparision of phytochemical and antioxidative potential of fresh fruit and traditional products (juice and sweet preserve) of $\mathrm{R}$ idaeus L. grown in mountain region 'Golija' (Serbia). The study confirmed a considerable level of bioactive compounds such as total phenols, flavonoids, tannins, anthocyanins and
Vitamin C in studied samples. Statistical analyses showed significant differences among tested samples in content of bioactive compounds mentioned above, with exception of anthocyanine (in juice and sweet preserve). Moreover, the power antioxidant activity of $R$. idaeus $\mathrm{L}$ samples was found, particularly in juice and sweet preserve. The current results indicate promising perspective for the exploitation of the 
572

fresh fruits and traditional products of wild grown $\mathrm{R}$ idaeus as food antioxidant diet and nutraceutical. Bearing in mind that the wild raspberry grows without addition of fertilizers, pesticides and other additives compared to cultivated raspberry it could be an excellent nutritional alternative.

\section{Acknowledgements}

Authors are grateful for support of Ministry of Education, Science and Technological Development of the Republic of Serbia for financing the Projects No. 3105.

\section{References}

Alice LA, Campbell CS (1999). Phylogeny of Rubus (Rosaceae) based on nuclear ribosomal DNA internal transcribed spacer region sequences. American Journal of Botany 86(1):81-97.

Amakura Y, Umino Y, Tsuji S, Tonogai Y (2001). Influence of jam processing on the radical scavenging activity and phenolic content in berries. Journal of Agricultural and Food Chemistry 48(12):6292-6297.

Bartolomé AP, Rupérez P, Fúster C (1995). Pineapple fruit: morphological characteristics, chemical composition and sensory analysis of Red Spanish and Smooth Cayenne cultivars. Food Chemistry 53(1):75-79.

Bobinaitė R, Viškelis P, Venskutonis PR (2012). Variation of total phenolics, anthocyanins, ellagic acid and radical scavenging capacity in various raspberry (Rubus spp.) cultivars. Food Chemistry 132:1495-1501.

Brighente IMC, Dias M, Verdi LG, Pizzolatti MG (2007). Antioxidant activity and total phenolic content of some Brazilian species. Pharmaceutical Biology 45(2):156-161.

Çekiç C, Özgen M (2010). Comparison of antioxidant capacity and phytochemical properties of wild and cultivated red raspberries (Rubus idaeus L.).Journal of Food Composition and Analysis 23(6):540-544.

Chen L, Xin X, Zhang H, Yuan Q (2013). Phytochemical properties and antioxidant capacities of commercial raspberry varieties. Journal of Functional Foods 5(1):508-515.

Gasperotti M, Masuero D, Vrhovsek U, Guella G, Mattivi F (2010). Profiling and accurate quantification of Rubus ellagitannins and ellagic acid conjugates using direct UPLC-Q-TOF HDMS and HPLC$\mathrm{DAD}$ analysis. Journal of Agricultural and Food Chemistry 58(8):4602-4616.

Gülçin I, Topal F, Çakmakçi R, Bilsel M, Gören AC, Erdogan U (2011). Pomological features, nutritional quality, polyphenol content analysis, and antioxidant properties of domesticated and 3 wild ecotype forms of raspberries (Rubusidaeus L.). Journal of Food Science 76(4):585-593.

Hassani S, Shariatpanahi M, Tavakoli F, Nili-Ahmadabadi A, Abdollahi M (2015). The changes of bioactive ingredients and antioxidant properties in various berries during jam processing. International Journal of Biosciences 6:172-179.

Horwitz W (1975). Official methods of analysis (Vol. 222). Washington, DC: Association of Official Analytical Chemists.

Hosu A, Cristea VM, Cimpoiu C (2014). Analysis of total phenolic, flavonoids, anthocyanins and tannins content in Romanian red wines: Prediction of antioxidant activities and classification of wines using artificial neural networks. Food Chemistry 150:113-118.
Hussein HA,Ewadh MJ, AL Gazally ME (2017). Detection and estimation of tannic acid in Rubus idaeus (red raspberry) as natural chelating agent for iron using HPLC. Research Journal of Pharmaceutical Biological and Chemical Sciences 8(2):345-351.

Jakovljević VD, Milićević JM, Đelić GT, Vrvić MM (2016). Antioxidant activity of Ruscus species from Serbia: Potential new sources of natural antioxidants. Hemijska Industrija 70(1):99-106.

Kadakal Ç, Duman T, Ekinci R (2017). Thermal degradation kinetics of ascorbic acid, thiamine and riboflavin in rosehip (Rosa canina $\mathrm{L})$ nectar. Food Science and Technology 38(4), http://dx.doi.org/10.1590/1678$457 \times 11417$.

Karakashova L, Stamatovska V, Babanovska-Milenkovska F (2012). The quality properties of raspberry jams with different sweeteners. In: International Symposium for Agriculture and Food, XXXVII FacultyEconomy Meeting, IV Macedonian Symposium for Viticulture and Wine Production, VII Symposium for Vegetables and Flower Production, Skopje, Macedonia, 12-14December 2012,pp 848-855.

Kuskoski EM, Asuero GA, Troncoso AM, Mancini-Filho J, Fett R(2005). Aplicación de diversos métodos químicos para determinar actividad antioxidante em pulpa de frutos. Food Science and Technology 25(4):726-732

Kim DO, Padilla-Zakour OI (2004).Jam processing effect on phenolics and antioxidant capacity in anthocyanin-rich fruits: cherry, plum, and raspberry.Journal of FoodScience 69(9):S395-S400.

Koponen JM, Happonen AM, Mattila PH, Törrönen AR (2007). Contents of anthocyanins and ellagitannins in selected foods consumed in Finland. Journal of Agricultural and Food Chemistry 55(4):16121619.

Kostecka-Gugała A, Ledwożyw-Smoleń I, Augustynowicz J, Wyżgolik G, Kruczek M, Kaszycki P (2015). Antioxidant properties of fruits of raspberry and blackberry grown in central Europe. Open Chemistry 13(1):1313-1325.

Krauze-Baranowska M, Majdan M, Hałasa R, Głód D, Kula M, Fecka I, Orzet A (2014). The antimicrobial activity of fruits from some cultivar varieties of Rubus idaeus and Rubus occidentalis. Food \& Function 5(10):2536-2541.

Le Bourvellec C, Gouble B, Bureau S, Reling P, Bott R, Ribas-Agusti A, Audergon J-M, Renard CMGC (2018). Impact of canning and storage on apricot carotenoids and polyphenols. Food Chemistry 240:615-625.

Mapson LW (1970). Biosynthesis of ethylene and the ripening of fruit. Endeavour 29:29-33.

Mazur SP, Nes A, Wold AB, Remberg SF, Aaby K (2014). Quality and chemical composition of ten red raspberry (Rubus idaeus L.) genotypes during three harvest seasons. Food Chemistry 160:233-240.

Mikulic-Petkovsek M, Schmitzer V, Slatnar A, Stampar F, Veberic R(2012). Composition of sugars, organic acids, and total phenolics in 25 wild or cultivated berry species. Journal of Food Science 77(10):1064-1070.

Milivojevic J, Maksimovic V, Nikolic M, Bogdanovic J, Maletic R, Milatovic D (2011). Chemical and antioxidant properties of cultivated and wild Fragaria and Rubus berries.Journal of Food Quality34(1):1-9.

Mullen W, Mcginn J, Lean MEJ, Maclean MR, Gardner P, ... Crozier A (2002). Ellagitannins, flavonoids, and other phenolics in red raspberries and their contribution to antioxidant capacity and vasorelaxation 
properties. Journal of Agricultural and Food Chemistry 50(18):51915196.

Pantelidis GE, Vasilakakis M, Manganaris GA, Diamantidis GR (2007). Antioxidant capacity, phenol, anthocyanin and ascorbic acid contents in raspberries, blackberries, red currants, gooseberries and Cornelian cherries. Food Chemistry 102(3):777-783.

Poyrazoğlu E, Gökmen V, Artik N (2002). Organic acids and phenolics compouns in pomegrantates (Punica granatum L.) grown in Turkey. Journal of Food Composition and Analysis 15(5):567-575.

Pritts MP (2003). Raspberries and related fruits. In: Encyclopedia of Food Sciences and Nutrition (SecondEdition) 4916-4921.

Rauha JP, Remes S, Heinonen M, Hopia A, Kähkönen M,... Vuorela P (2000). Antimicrobial effects of Finnish plant extracts containing flavonoids and other phenolic compounds. International Journal of Food Microbiology 56(1):3-12.

Rickman JC, Barrett DM, Bruhn CM (2007). Nutritional comparison of fresh, frozen and canned fruits and vegetables. Part 1 . Vitamins $C$ and $B$ and phenolic compounds. Journal of the Science of Food and Agriculture 87(6):930-944.

Sablani SS, Andrews PK, Davies NM, Walters T, Saez H, ... Mohekar PR (2010). Effect of thermal treatments on phytochemicals in conventionally and organically grown berries. Journal of the Science of Food and Agriculture 90(5):769-778.

Sariburun E, Sahin S, Demir C, Turkben C, Uylaser V (2010). Phenolic content and antioxidant activity of raspberry and blackberry cultivars. Journal of FoodScience 75(4):328-335.

Serrano M, Díaz-Mula HM, Valero D (2011). Antioxidant compounds in fruits and vegetables and changes during postharvest storage and processing. Stewart Postharvest Review 7(1):1-10.

Siriwoharn T, Wrolstad RE, Finn CE, Pereira CB (2004). Influence of cultivar, maturity, and sampling on blackberry (Rubus L. hybrids) anthocyanins, polyphenolics, and antioxidant properties. Journal of Agricultural and Food Chemistry 52(26):8021-8030.

Skrovankova S, Sumczynski D, Mlcek J, Jurikova T, Sochor J (2015). Bioactive compounds and antioxidant activity in different types of berries. International Journal of Molecular Sciences 16(10):2467324706.

Stevens R, Buret M, Duffé P, Garchery C, Baldet P, ... Causse M (2007). Candidate genes and quantitative trait loci affecting fruit ascorbic acid content in three tomato populations. Plant Physiology 143(4):19431953.

Takao T, Kitatani F, Watanabe N, Yagi A, Sakata K (1994). A simple screening method for antioxidants and isolation of several antioxidants produced by marine bacteria from fish and shellfish. Bioscience, Biotechnology and Biochemistry 58(10):1780-1783.
Tamer CE (2012). A Research on raspberry and blackberry marmalades produced from different cultivars. Journal of Food Processing and Preservation 36(1):74-80.

Van Boekel M, Pellegrini N, Fogliano V, Eisenbrand G (2010). A review on the beneficial aspects of food processing. Molecular Nutrition \& Food Research 54(9):1215-1247.

VedaS, Kamath A, Platel K, Begum K, Srinivasan K (2006). Determination of bioaccessibility of $\beta$-carotene in vegetables by in vitro methods. Molecular Nutrition \& Food Research 50(11):1047-1052.

Venskutonis PR, Dvaranauskaite A, Labokas J (2007). Radical scavenging activity and composition of raspberry (Rubus idaeus) leaves from different locations in Lithuania. Fitoterapia 78(2):162-165.

Wada L, Ou B (2002). Antioxidant activity and phenolic content of Oregon cranberries. Journal of Agricultural and Food Chemistry 50(12):34953500.

Wang SY, Lin HS (2000). Antioxidant activity in fruits and leaves of blackberry, raspberry, and strawberry varies with cultivar and developmental stage. Journal of Agricultural and Food Chemistry 48(2):140-146.

WangSY, Chen CT, Wang CY (2009). The influence of light and maturity on fruit quality and flavonoid content of red raspberries. Food Chemistry 112:676-684.

Zadernowski R, Naczk M, Nesterowicz J (2005). Phenolic acid profiles in some small berries. Journal of Agricultural and Food Chemistry 53(6):2118-2124.

Wootton-Beard PC, Moran A, Ryan L (2011). Stability of the total antioxidant capacity and total polyphenol content of 23 commercially available vegetable juices before and after in vitro digestion measured by FRAP, DPPH, ABTS and Folin-Ciocalteu methods. Food Research International 44(1):217-224.

Zafrilla P, Ferreres F, Tomás-Barberán FA (2001). Effect of processing and storage on the antioxidant ellagic acid derivatives and flavonoids of red raspberry (Rubus idaeus) jams. Journal of Agricultural and Food Chemistry 49(8):3651-3655.

Zhang Y, Zhang Z, Yang Y, Zu X, Guan DI, Guan Y (2011). Diuretic activity of Rubus idaens L (Rosaceae) in rats. Tropic Journal of Pharmaceutical Research 10(3):243-248.

Zorenc Z, Veberic R, Koron D, Mikulic-Petkovsek M (2017). Impact of raspberry (Rubus idaeus $\mathrm{L}$.) primocane tipping on fruit yield and quality. Notulae Botanicae Horti Agrobotanici Cluj-Napoca 45(2):417-424.

Tatić B (1972). FloraSRSrbije.SANU, Belgrade, Serbia. 